\title{
An experimental study of gill net and trammel net 'ghost fishing' off the Algarve (southern Portugal)
}

\author{
K. Erzini ${ }^{1, *}$, C. C. Monteiro ${ }^{2}$, J. Ribeiro$^{1}$, M. N. Santos ${ }^{2}$, M. Gaspar ${ }^{2}$, P. Monteiro ${ }^{1}$, \\ T. C. Borges ${ }^{1}$ \\ ${ }^{1}$ Unidade de Ciências e Tecnologias dos Recursos Aquáticos (UCTRA), Universidade do Algarve, P-8000 Faro, Portugal \\ ${ }^{2}$ IPIMAR CIM-Sul, P-8700 Olhāo, Portugal
}

\begin{abstract}
Four $100 \mathrm{~m}$ lengths of both monofilament gill nets and trammel nets were deployed at depths between 15 and $18 \mathrm{~m}$ off the coast of the Algarve (south of Portugal) between April 1995 and June 1996. The nets were set on a natural rocky bottom with one end cut loose to simulate lost nets. Changes in net structure (net height, effective fishing area, movement, colonisation, wear and tear) and their catches (species, sizes, numbers, and biomass) were monitored by divers. Similar patterns were observed in all the nets, with a sharp decrease in net height and effective fishing area, and an increase in visibility within the first few weeks. Net movement was negligible except in the case of interference from other fishing gears. Catch rates were initially comparable to normally fished gill nets and trammel nets in this area, but decreased steadily over time. No sea birds, reptiles or mammals were caught in any of the 8 nets. Catches were dominated by fish ( $89 \%$ by number, at least 27 species), in particular by sea breams (Sparidae) and wrasses (Labridae). Under the conditions experienced throughout the study the fishing lifetime of a 'lost' net is between 15 and $20 \mathrm{wk}$. Based on an exponential model, we estimated that $100 \mathrm{~m}$ lengths of gill net and trammel net will catch 314 and 221 fish respectively over a 17 wk period. However, we consider this to be an underestimate due to high rates of predation and scavenging by octopuses, cuttlefish, moray eels, conger eels, and other fish such as the wrasse Coris julis. When the nets were surveyed in the following spring, 8 to 11 mo after being deployed, they were found to be completely destroyed or heavily colonised by algae and had become incorporated into the reef.
\end{abstract}

KEY WORDS: Lost gear - Ghost fishing - Gill net · Trammel net · Catches · Incidental mortality

\section{INTRODUCTION}

The impact of lost fishing gear on the environment has aroused considerable concern in recent years (Laist 1995). Of particular concern is the danger posed to rare and endangered species of marine mammals, sea birds and turtles (Degange \& Newby 1980, Henderson 1984, Millner 1985, Carr 1987, Perrin et al. 1994). It has been estimated that millions of sea birds and thousands of turtles and marine mammals may die each year when entangled or trapped in lost gear (Colema et al. 1983). In commercial fisheries, incidental mortality due to gear over which the fisherman has lost control, may be highly significant (Chopin et al. 1995). 'Ghost fishing' can be defined as the capacity of

-E-mail: kerzini@ualg.pt a fishing gear to continue to fish after it has been lost and the fisherman has lost control. For example, Breen (1987) estimated that ghost fishing traps caught an amount equivalent to $7 \%$ in weight of the reported commercial catch of Dungeness crab. Similarly, lost fish traps were estimated to catch a quantity equivalent to $3-13.5 \%$ of the total Kuwait landings (Mathews et al. 1987), and the decline in Gulf of St. Lawrence Queen crab has been partially attributed to mortality associated with lost crab traps (Blois 1992).

In addition to being a source of mortality, lost fishing gears have the potential to interfere with normal fishing and diving operations and may even be a major cause of further gear loss. Lost gears may also have negative impacts on the environment, particularly in terms of habitat degradation. Both types of detrimental impact have been observed in Algarve (south Portu- 
gal) waters, with complaints from commercial fishermen about the amount of lost gear in certain areas, and claims that artificial reefs have become so heavily fouled with lost nets that reef fish may have reduced access.

While the possibility of partial or total gear loss exists in all fishing activities, certain types of gears, in particular 'active' gears such as trawls and seines, are not a major source of concern as their catching ability is negligible or non-existent once lost. On the other hand, 'fixed' or 'static' gears, such as gill nets, trammel nets, and traps, may continue to fish with significant efficiency, at least in the short term (Carr et al. 1992, Kaiser et al. 1996).

In southern Portugal, gill nets and trammel nets are 2 of the most widely used gears. In 1993 the Algarve commercial fishing fleet consisted of 3414 boats of which 2996 belonged to the 'local' category $(<10 \mathrm{~m}$ in length), 416 were 'coastal' boats $(>10 \mathrm{~m})$, and only 2 were classified as 'offshore' or long distance trawlers. 827 trammel net and 496 gill net licences were issued. Based on the numbers of fishing boats per category, the numbers of licences issued, and the maximum lengths of fixed nets allowed by legislation, we estimated the total length of netting potentially in use in Algarve waters as $1901 \mathrm{~km}$ of gill nets and $1452 \mathrm{~km}$ of trammel nets.

The European Community directive on habitats and species obliges the member states to take measures to minimise the adverse effects of fishing activity, and under the Common Fisheries Policy, each member state is responsible for the control and management of local fisheries. In this context, it is important to develop standard methodologies for collecting information on the extent of ghost fishing, and for identification and quantification of impacts, thereby contributing to better management and conservation

Although there have been some studies on the behaviour and evolution of lost nets and the quantification of their different impacts in northern European waters (Bord Iascaigh Mhara (BIM) 1995, Kaiser et al. 1996], there is no information available for southern European waters. This paper reports the results of a study on the changes in structure, degradation, movement, and catches of experimentally set ghost fishing gill nets and trammel nets in Algarve waters.

\section{MATERIALS AND METHODS}

Experimental sites. Each site had to fulfill the following criteria: (1) an area where normal fishing activity with gill nets, trammel nets, longlines, traps, and pots takes place $;$ (2) proximity to support base for diving operations and within diving depth limitations; (3) pres- ence of natural reef bottom, permitting the simulated loss of nets snagged on the bottom (according to local fishermen, the scarcity of hard bottom in Algarve waters results in concentration of fishing effort around such reefs, leading to a concentration of lost gear); (4) proximity to artificial reefs, permitting surveillance, and reducing the likelihood of interference from local fishermen; (5) existence of fish community data, allowing interpretation of experimental results (Erzini et al. 1996a, b, Santos et al. 1996).

The 2 experimental sites are very similar, situated approximately 1 mile off the Praia de Faro, southern Portugal $\left(36^{\circ} 58^{\prime}\right.$ to $36^{\circ} 59^{\prime} \mathrm{N}$ and $7^{\circ} 59^{\prime}$ to $8^{\circ} 00^{\prime} \mathrm{W}$ ), and less than half a mile apart. Both are rocky outcrops protruding from a sandy bottom, 200 to $300 \mathrm{~m}$ in length and $50 \mathrm{~m}$ wide at the most. Maximum depth is approximately $18 \mathrm{~m}$ at the base of the reefs, with a maximum reef height of $3 \mathrm{~m}$. The area is fished by 'local' category boats from Faro, Olhão, and Quarteira using gill nets, trammel nets, purse seines, longlines, traps, and octopus pots.

Experimental nets and their deployment. Each experimental net consisted of $100 \mathrm{~m}$ of monofilament gill net or $100 \mathrm{~m}$ of monofilament trammel net of the type used locally. Gill nets were of $60 \mathrm{~mm}$ stretched mesh, while trammel nets consisted of an inner panel of $60 \mathrm{~mm}$ stretched mesh between two $110 \mathrm{~mm}$ stretched mesh panels. Gill nets were 40 meshes deep while trammel nets were 32 meshes (inner net) deep. Each $100 \mathrm{~m}$ section of netting was fixed to a $40 \mathrm{~kg}$ block at one end while the other end remained free. Each net was marked at $5 \mathrm{~m}$ intervals with neutrally buoyant numbered floats and lengths of dark cord.

The first 2 groups of nets ( $A$ and $B$ ) each consisting of 1 gill net and 1 trammel net were set on April 26, 1995 from a research boat. On August 30, 1995, group B was removed and replaced by group $\mathrm{C}$, which also consisted of $100 \mathrm{~m}$ of gill net and $100 \mathrm{~m}$ of trammel net. Instead of marker cords stretching from the headline to the leadline at $5 \mathrm{~m}$ intervals, short lengths were used. A final group of nets (D), identical to group C, replaced group A on June 11, 1996.

Due to bad weather and/or poor visibility, nets could not be deployed or monitored during the winter months. However, attempts were made to locate the nets in the following spring and summer.

Underwater monitoring. Nets of groups $A$ and $B$ were monitored monthly, alternating between group $A$ and $B$ at 2 wk intervals. Based on experience with these nets, the monitoring frequency was decreased over time for groups $C$ and D: weekly during the first month, every 2 wk during the second month, and monthly thereafter. Two teams of 2 divers were used to monitor each group of nets. Since the nets were not marked at the surface, a GPS (Global Positioning Sys- 
tem) receiver was used to locate the experimental sites. For net groups A, B, and C, monitoring consisted of 3 consecutive days of diving, while monitoring took place over $2 \mathrm{~d}$ in the case of net group $\mathrm{D}$.

On the first day, 2 divers swam along the gill net while the other pair did the same for the trammel net. At intervals of $5 \mathrm{~m}$, corresponding to the spacing of the numbered floats, the height of the net was measured as the vertical distance between the leadline and the headline (Kaiser et al. 1996). All organisms caught in the nets were tagged with small aluminium tags (Kaiser et al. 1996). For each organism, the following data were recorded: species, total length to the $\mathrm{cm}$ below, the state of the catch, and the sector of the net (i.e. between float numbers $i$ and $i+1$. A 4 point scale was used to classify the state of the catch: (1) unidentifiable remains, (2) decomposed but identifiable, (3) recently dead, and (4) still alive.

This procedure was repeated the following day, with the exception of the measurement of net height. Photographs were taken of the sections of net between floats 3 and 4,9 and 10 , and 16 and 17. Direct observations of the degree of wear (i.e. abrasion or tears in the netting) and net movement were also made.

On the third and final day of each sampling period, the procedure of the previous day was repeated, replacing photography with a video recording of the entire length of each net. In the case of net group D, as monitoring was reduced to 2 consecutive days, 1 rather than 2 estimates of $24 \mathrm{~h}$ catch rates was made.

Effective fishing area, catches and $24 \mathrm{~h}$ catch rates. Using the height of the net at each float, the approximate fishing area of each net was estimated using the following formula:

$$
A_{1,1+1}=D \times\left(H_{1}+H_{1+1}\right) / 2
$$

where $A_{i, i+1}$ is the area between floats $i$ and $i+1, D$ is $5 \mathrm{~m}$, and $H_{i}$ and $H_{i+1}$ are distances between the headline and the leadline at floats $i$ and $i+1$. The total area, $A_{t}$, is the sum of all the areas between floats and can be used as an index of the fishing capacity of the experimental net:

$$
A_{\mathrm{t}}=\sum A_{i,+1}
$$

Tagging of catches on the first and second day allowed animals captured over a $24 \mathrm{~h}$ period to be recorded. In order to evaluate the long-term impact of the experimental nets on both target and nontarget species, exponential models were fitted to the pooled daily catch data in numbers $\left(N_{t}=N_{0} \mathrm{e}^{-r t}\right)$ and in weight $\left(B_{t}=B_{0} \mathrm{e}^{-r t}\right) . N_{t}$ and $B_{t}$ are the $24 \mathrm{~h}$ catches in numbers and weight $(\mathrm{g}), N_{0}$ and $B_{0}$ are the intercepts, $r$ is the parameter defining the rate of decrease, and $t$ is the number of days after deployment. The above equations were used to estimate the total catches for the experimental gill and trammel nets over a $17 \mathrm{wk}$ period. This period was chosen since catches after 15 to $20 \mathrm{wk}$ were negligible.

Estimated lengths were converted to weights using weight-length relationships ( $W=\mathrm{a} L^{\mathrm{b}}$ ) determined for the species in the Algarve or in Portuguese waters (Canário et al. 1994, Gonçalves et al. 1997). For species for which weight-length relationships were not available from this region, published equations from other areas were used.

\section{RESULTS}

Due to bad weather and/or poor visibility, it was not possible to obtain data for net groups $A$ and $B$ during the first 2 wk after deployment. In general, the same patterns were observed in both types of nets and for all 4 groups of nets. Net height decreased dramatically within the first few weeks after deployment and then stabilised or decreased gradually thereafter (Fig. 1): For gill nets the mean net height decreased approximately $50 \%$ within the first $3 \mathrm{wk}$, while the reduction in trammel net height was between 60 and $70 \%$ during the same period. Both gill net $C$ and trammel net $C$, which were set at the end of August, decreased more sharply in height than net groups $A, B$, and D which were deployed in April and June.

The reduction in height of the nets led to a rapid decrease in the effective fishing area after deployment of the nets (Fig. 2). For example, net area decreased to $50 \%$ after $1 \mathrm{wk}$ for gill net $\mathrm{C}$, while the area of trammel net $\mathrm{C}$ decreased to $39 \%$. After $17 \mathrm{wk}$, gill nets $\mathrm{A}$ and $\mathrm{B}$ and trammel nets $A$ and $B$ were at 21 and $45 \%$, respectively, of their original area. Considerable variation in net height along the nets was observed throughout the study.

Net visibility increased sharply as particulate matter and detritus accumulated on the monofilament (Fig. 3a). Over time the nets were colonised by various species, primarily macrophytes, which after 3 mo completely blocked the meshes of some parts of the nets. Netting which came into contact with the reef became heavily overgrown and blended into the background, making identification difficult. Nets which were surveyed after the winter, less than a year after being deployed, were completely destroyed. Only sections of the leadline and some netting and floats could be found. These remnants of net that were found were completely colonised by biota (Fig. 3b).

Considerable net damage was observed over time, with large holes in the netting after 3 to 4 mo. For example, the leadline, headline and part of the netting of gill net $B$ were completely torn after becoming entangled with fishing gear, most probably a longline. 

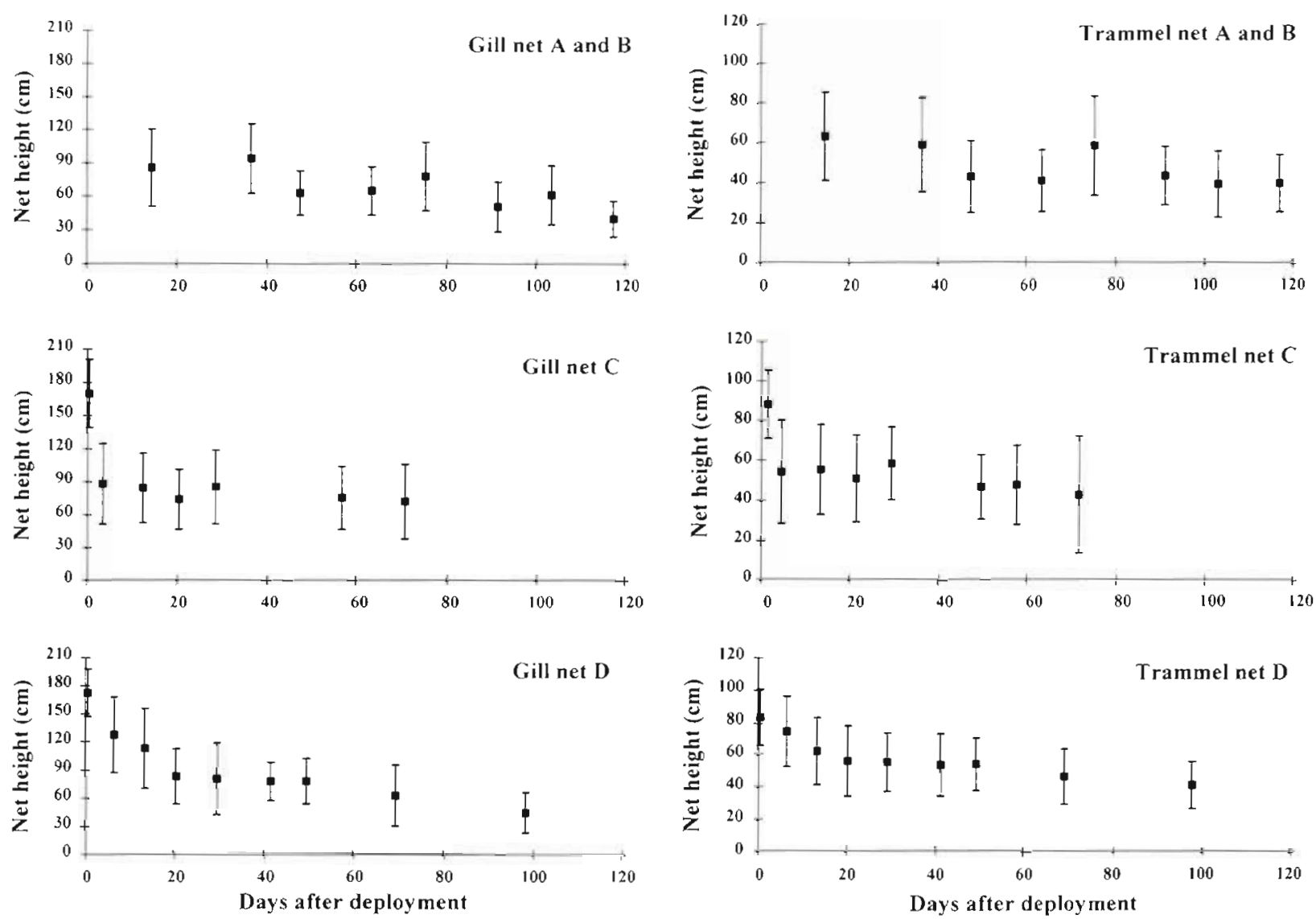

Fig. 1. Mean gill and trammel net height ( $\pm 2 \mathrm{SD}$ ) measured at $5 \mathrm{~m}$ intervals over a $120 \mathrm{~d}$ period after net deployment for net groups A and B, C, and D

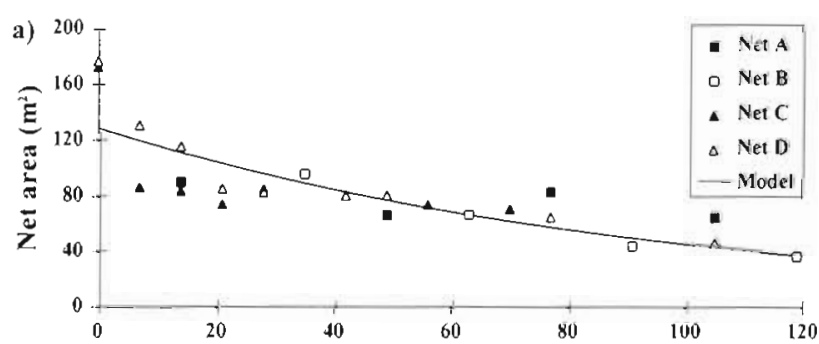

b) $100-$

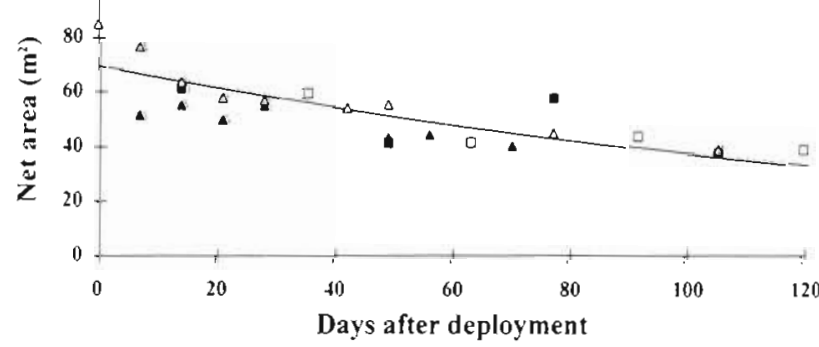

Fig. 2. Effective fishing area of the nets over a $120 \mathrm{~d}$ period after net deployment, with the fitted exponential models. (a) Gill nets, (b) trammel nets
There was little net movement except at the loose ends, at the points where the nets had been torn through interaction with fishing gear, and at one of the fixed ends which we suspect had been lifted deliberately/accidentally by fishermen.

The highest $24 \mathrm{~h}$ catch rates were made immediately after the nets had been deployed (Fig 4a, b), with gill nets catching more than the trammel nets. Initial catch rates were comparable to normally fished nets: for example, in an ongoing comparative fixed gear selectivity study (Erzini unpubl. data) an average of 8.9 fish per net were caught in 105 gill nets (45 to $50 \mathrm{~m}$ in length, $60 \mathrm{~mm}$ stretched mesh monofilament). Over time, the catches decreased gradually. However, even after more than 4 mo in the water, some fish and other organisms were still being caught. No marine mammals, sea birds, or reptiles were caught. Based on the exponential model, the estimated total numbers of fish caught by $100 \mathrm{~m}$ lengths of gill net and trammel net during the first $120 \mathrm{~d}$ period after deployment were respectively 344 and 221 (Table 1).

Total catches in terms of weight also decreased in an exponential manner over time for the gill nets 

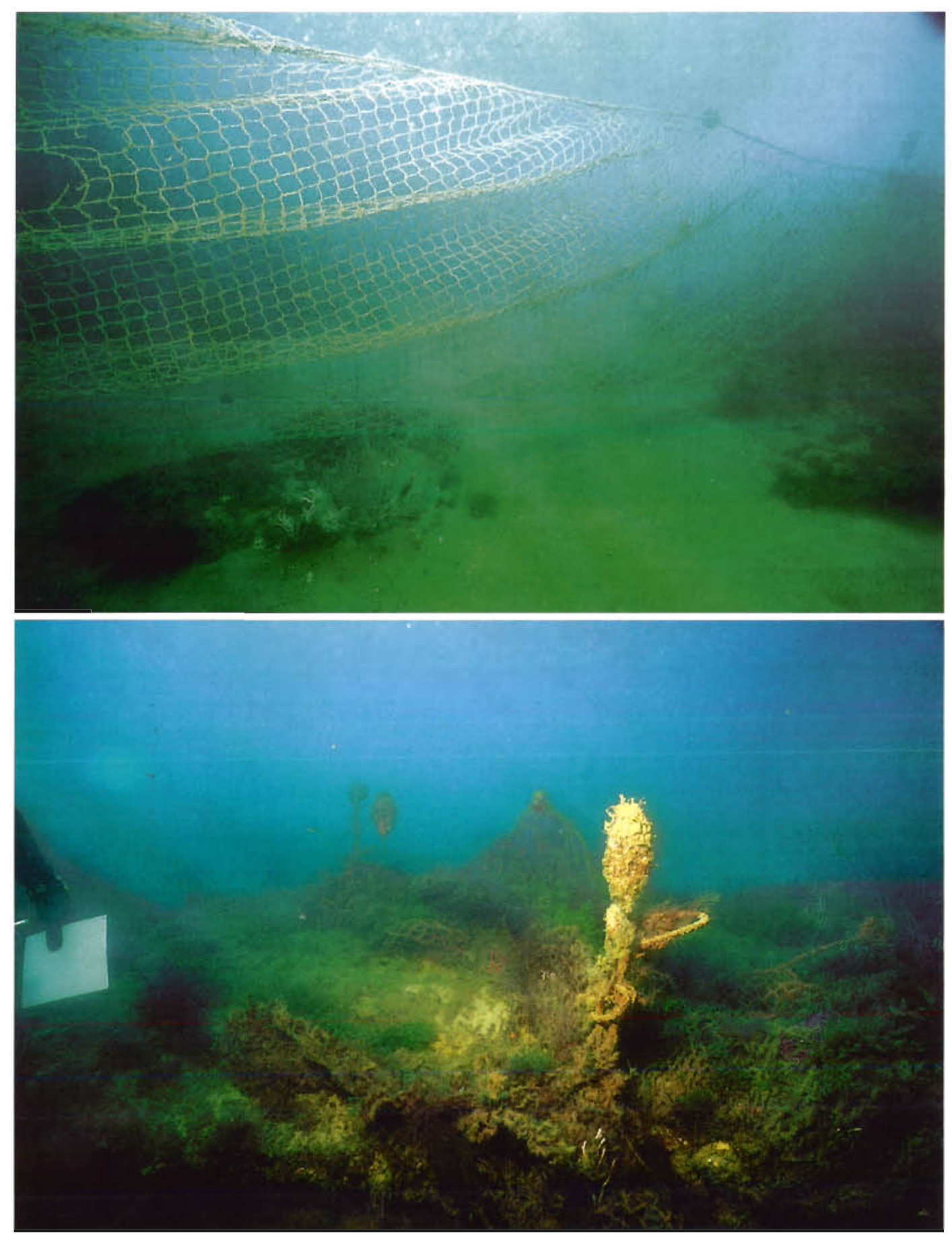

Fig. 3. (a) Gill net 4 wk after deployment, showing signs of wear and tear and increased visibility due to accumulation of particulate matter. (b) Remains of a gill net less than a year after deployment showing heavy infestation and colonisation

(Fig. 4c), although variability was greater in comparison with catches in numbers. For the trammel nets there was a less pronounced decrease over time (Fig. 4d).

The experimental nets caught a total of 39 species belonging to 23 families and 4 main groups: molluscs, gastropods, crustaceans and osteichthyes (Table 2). Only 3 individual gastropods were caught $(0.6 \%)$, while crustaceans and fish accounted for 10.1 and $88.8 \%$ of the catches respectively. Three species of fish accounted for $41.9 \%$ of the total catch by numbers: Diplodus bellottii, D. vulgaris, and Scorpaena notata. In particular, Sparidae, which are economically valuable, dominated the catch with 33 and $29 \%$ for the gill and trammel nets respectively. 
a)

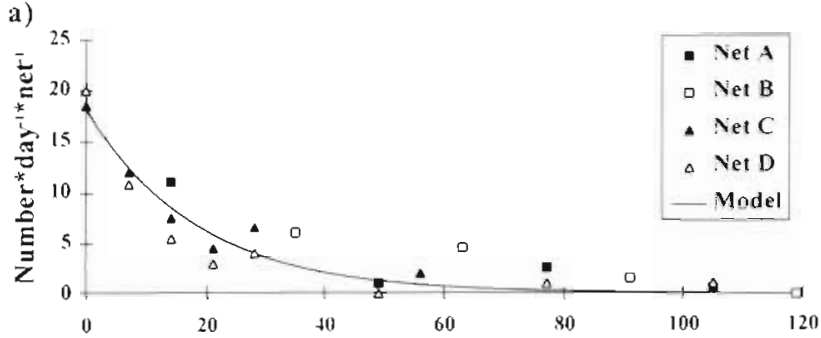

c)

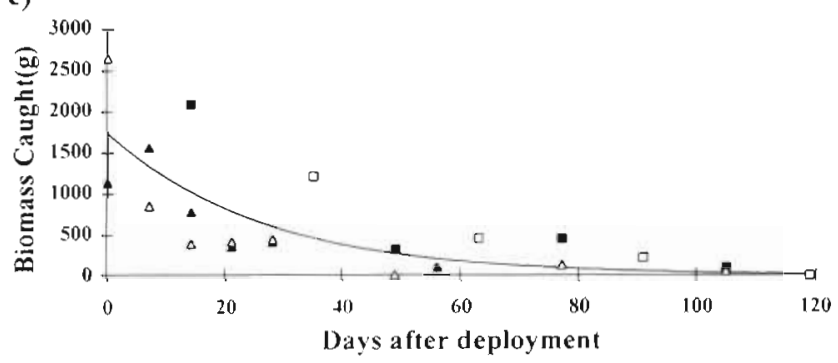

b)

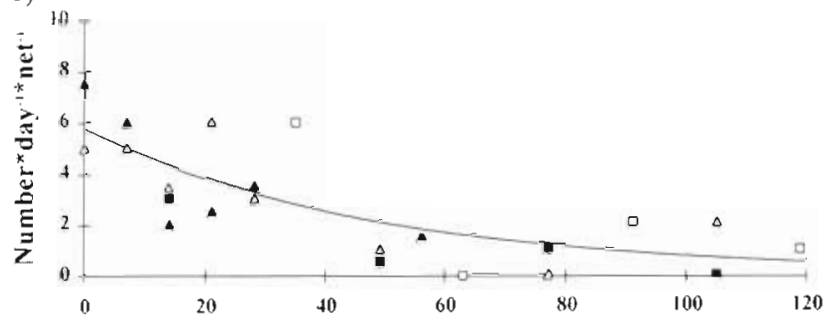

d)

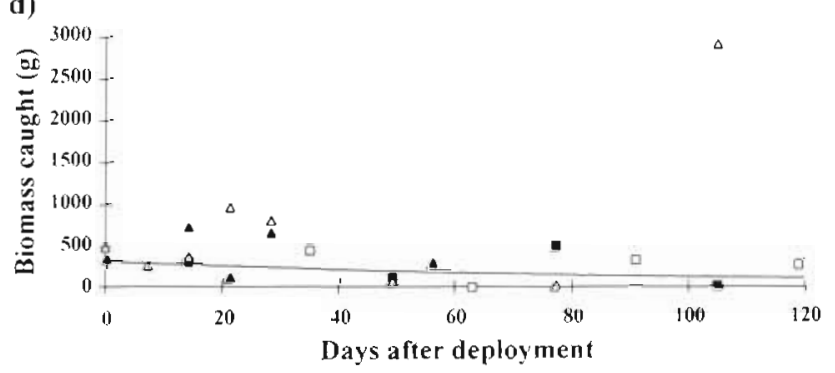

Fig. 4. 24 h catch rates over a $120 \mathrm{~d}$ period after net deployment, with fitted exponential models. Catch in numbers for (a) gill nets and (b) trammel nets, catch in weight for (c) gill nets and (d) trammel nets

\section{DISCUSSION}

The results presented represent a limited number of many possible scenarios of net loss. Due to a number of constraints, nets were set in relatively shallow water, corresponding to depths at the lower end of the range normally fished by Algarve fishermen. The relatively shallow depth has important implications in terms of changes in net structure and catch characteristics because of light penetration and consequently the rates of colonisation by algae. In addition, weather conditions and bottom currents have a stronger influence at these relatively shallow depths.

The nets were set during periods of good weather conditions. Thus we were not able to evaluate the effect of storm conditions soon after deployment. Such conditions, which are common during the winter, might have brought about considerably different changes in terms of the rate of net collapse, and consequently in terms of the catches.
The way in which the nets were deployed, entirely on a natural rocky bottom, with one end fixed and the other loose, may not be characteristic of normally lost nets. Nets lost on soft bottom may have a very different evolution and impact.

The effective fishing lifetime of a net lost under the experimental conditions in the present study is a maximum of 15 to $20 \mathrm{wk}$. During this period, catches dropped sharply during the first few weeks, with a gradual decline thereafter. The observed pattern is due to changes in net shape, increasing net visibility, decreasing net height and effective fishing area, and increasing wear and tear, all contributing to a decline in $24 \mathrm{~h}$ catch rate per $100 \mathrm{~m}$ of gill net or trammel net. As noted above, these results are highly site and season specific. Nets set in winter or in deeper waters or on soft bottom would no doubt have evolved differently, resulting in different catch rates and patterns.

Over the 15 to $20 \mathrm{wk}$, the cumulative catch in numbers and in biomass may be considerable. Our estimates based on daily catch rates should be considered

Table 1 Parameter estimates of exponential model $[Y=a \times \exp (-r \times$ days after deployment)] fit to net area and to daily catch in numbers and in weight

\begin{tabular}{|llrrrrr|}
\hline Net & Variable & \multicolumn{1}{c}{ S } & SE & \multicolumn{1}{c}{ SE } & MSE \\
\hline Gill & Area & 129.270 & 8.649 & 0.0105 & 0.00180 & 435.99 \\
Trammel & Area & 69.760 & 3.145 & 0.0062 & 0.00102 & 24 \\
Gill & Catch (n) & 18.160 & 1.294 & 0.0542 & 0.00710 & 68.12 \\
Trammel & Catch (n) & 5.739 & 0.711 & 0.0204 & 0.00578 & 25 \\
Gill & Weight (g) & 1742.107 & 284.945 & 0.0378 & 0.01214 & 2.06 \\
Trammel & Weight (g) & 326.420 & 156.795 & -0.0103 & 0.00595 & 20 \\
\end{tabular}


Table 2. Species composition of the experimental net catches

\begin{tabular}{|c|c|c|c|c|c|c|c|c|c|}
\hline \multirow[t]{2}{*}{ Group } & \multirow[t]{2}{*}{ Family } & \multirow{2}{*}{ Species } & \multicolumn{3}{|c|}{ Gill nets } & \multicolumn{3}{|c|}{ Trammel nets } & \multirow[t]{2}{*}{ Total } \\
\hline & & & $A$ and $B$ & $\mathrm{C}$ & $\mathrm{D}$ & $A$ and $B$ & C & D & \\
\hline \multirow[t]{4}{*}{ Crustaceans } & Galatheidae & Galathea strigosa & 1 & & & & & & 1 \\
\hline & Majidae & Maja squinado & 1 & 1 & & 2 & 3 & & 7 \\
\hline & Portunidae & Macropipus puber & & 1 & 1 & & & & 2 \\
\hline & Scyllaridae & Scyllarus arctus & 13 & 4 & 8 & 5 & 10 & 4 & 44 \\
\hline Gastropods & Cymatidae & Charonia lampas & 1 & & & & 2 & & 3 \\
\hline \multirow[t]{2}{*}{ Molluscs } & Volutidae & Cybium olla & & & & & & 1 & 1 \\
\hline & Sepiolidae & Sepla officinalis & & & & & & 2 & 2 \\
\hline \multirow[t]{28}{*}{ Osteichthyes } & Balistidae & Balistes carolinensis & & 1 & & & 2 & 2 & 5 \\
\hline & Blenniidae & Parablennius gattorugine & & 2 & & & & & 2 \\
\hline & Callionymidae & Callionymus lyra & & & 1 & & & & 1 \\
\hline & Carangidae & Caranx rhonchus & & 1 & 3 & 1 & & & $\cdot 5$ \\
\hline & & Trachurus trachurus & 8 & 7 & 1 & & 1 & 1 & 18 \\
\hline & Conger & Conger conger & & & & & & 1 & 1 \\
\hline & Gadidae & $\begin{array}{l}\text { Phycis phycis } \\
\text { Trysopterus luscus }\end{array}$ & $\begin{array}{l}3 \\
2\end{array}$ & $\begin{array}{l}1 \\
2\end{array}$ & 1 & & & & $\begin{array}{l}4 \\
5\end{array}$ \\
\hline & Haemulidae & Pomadaisys incisus & & 2 & 3 & 1 & & 2 & 8 \\
\hline & Labridae & Labrus merula & & & & & & 1 & 1 \\
\hline & & $\begin{array}{l}\text { Symphodus bailloni } \\
\text { Symphodus spp. }\end{array}$ & $\begin{array}{l}3 \\
5\end{array}$ & $\begin{array}{l}4 \\
2\end{array}$ & 18 & 1 & & 1 & $\begin{array}{r}27 \\
7\end{array}$ \\
\hline & Merluccidae & Merluccius merluccius & & & & & & 1 & 1 \\
\hline & Mugilidae & Mugil spp. & & & 1 & & & 1 & 2 \\
\hline & Mullidae & Mullus surmuletus & 1 & & 4 & & & & 5 \\
\hline & Scombridae & Scomber spp. & & 1 & & & & & 1 \\
\hline & & Scomber japonicus & 1 & 9 & 1 & & 1 & & 12 \\
\hline & Scorpaenidae & Scorpaena notata & 16 & 44 & 17 & 1 & 25 & 29 & 132 \\
\hline & Serranidae & $\begin{array}{l}\text { Serranus spp. } \\
\text { Serranus cabrilla }\end{array}$ & $\begin{array}{l}2 \\
3\end{array}$ & 6 & 5 & 2 & 2 & & $\begin{array}{r}2 \\
18\end{array}$ \\
\hline & Soleidae & Buglodissium luteum & 1 & & & & & & 1 \\
\hline & Sparidae & $\begin{array}{l}\text { Dentex gibbosus } \\
\text { Diplodus annularis }\end{array}$ & 1 & 4 & 2 & & 1 & & $\frac{1}{7}$ \\
\hline & & Diplodus bellottu & 14 & 15 & 23 & & & 1 & 53 \\
\hline & & $\begin{array}{l}\text { Diplodus cervinus } \\
\text { Diplodus puntazzo }\end{array}$ & & & & 3 & & $\begin{array}{l}2 \\
1\end{array}$ & $\begin{array}{l}2 \\
4\end{array}$ \\
\hline & & Diplodus sargus & 2 & 1 & & 1 & & & 4 \\
\hline & & Diplodus spp. & 2 & 6 & 1 & & 2 & & 11 \\
\hline & & Diplodus vulgaris & 7 & 2 & 15 & 4 & 4 & 7 & 39 \\
\hline & & Pagellus acarne & & & & & & 1 & 1 \\
\hline & & $\begin{array}{l}\text { Sarpa salpa } \\
\text { Spondyliossoma cantharus }\end{array}$ & & $\begin{array}{l}1 \\
2\end{array}$ & $\begin{array}{l}2 \\
2\end{array}$ & 5 & & 11 & $\begin{array}{r}19 \\
4\end{array}$ \\
\hline & & Not identified & 1 & 29 & 14 & 2 & 20 & 6 & 72 \\
\hline & & Total & 88 & 148 & 123 & 28 & 73 & 75 & 535 \\
\hline
\end{tabular}

underestimates for a number of reasons. Based on our experience and observations, there may be considerable predation and scavenging of fish caught in the nets. Thus some fish may be caught and disappear completely from the net during the interval between marking of captured fish and quantification of new catches $24 \mathrm{~h}$ later. This is probably particularly true for soft-bodied fish such as red mullets (Mullus surmuletus). Important predators include octopuses, cuttlefish, conger eels, moray eels, and wrasses such as Coris julis, which were often observed feeding on recently caught (live) fishes. Carr et al. (1992) also reported predation by a wrasse, the cunner Tautogolabrus adspersus, on fish and lobsters caught in gill nets.
It is interesting to note that the nets eventually became incorporated into the reefs, acting as a base for many colonising plants and animals. The colonised nets then provided a complex habitat which was attractive to many organisms. For example, large schools of juvenile fish were often observed in the vicinity of these heavily colonised nets, which may provide a safe haven from predators.

To date, relatively few experimental studies of the impact and evolution of ghost fishing nets have been carried out. In a parallel study $90 \mathrm{~m}$ sections of gill and trammel nets were set inshore in Wales (Kaiser et al. 1996). These nets immediately caught large numbers of dogfish, which caused the nets to collapse and the $24 \mathrm{~h}$ catch rate of fish and the vertical fishing area to 
decrease dramatically. The considerable biomass of decaying dogfish attracted large numbers of invertebrate scavengers, resulting in crustacean catches reaching a peak approximately $6 \mathrm{wk}$ after the nets had been deployed.

Unlike our study, the species composition of the catches changed over time, with $24 \mathrm{~h}$ fish catches approaching zero after $70 \mathrm{~d}$, while invertebrates continued to be caught at low rates more than 4 mo after the nets had been deployed. Based on the exponential model fitted in both studies to 24 h catch rates against days after deployment, the gill nets in both studies caught similar numbers of fish during the first $120 \mathrm{~d}$ after deployment, while the trammel nets in the Welsh study caught fewer fish (Kaiser et al. 1996). The equations reported by Kaiser et al. (1996) are the following: (1) fish (gill net), In $N=3.08-6.06$ Indays; (2) fish (trammel net), $\ln N=2.31-0.517$ lndays; (3) crustaceans (gill net), $\ln N=3.53-0.407$ lndays; and (4) crustaceans (trammel net), $\ln N=4.11-0.687 \ln$ days.

The results reported by Kaiser et al. (1996) are more comparable to those of Carr et al. (1992) who deployed two $100 \mathrm{~m}$ sections of $130 \mathrm{~mm}$ stretched mesh gill nets at $20 \mathrm{~m}$ depth in Buzzards Bay, Massachusetts, USA, and monitored them over a 2 yr period. Skates and dogfish, along with a number of finfish species, were caught in significant numbers early on, while lobsters and other crustaceans continued to be caught throughout the study.

Simulated lost pelagic or drift gill net studies have also been carried out (Gerrodette et al. 1987, Breen 1990). Gerrodette et al. (1987) monitored $113 \mathrm{~mm}$ mesh $9 \mathrm{~m}$ deep monofilament nets $(50,100,350$, and $1000 \mathrm{~m}$ in length) and found that the nets collapsed soon after deployment and that relatively few fish or other organisms were caught in the resulting bundle of netting. Mio et al. (1990) deployed 5 pelagic gill nets, each $1200 \mathrm{~m}$ in length, and reported that after 4 mo all had collapsed, forming a large mass of netting.

A number of authors have reported on the long-term impacts of lost nets, particularly in deeper waters (Breen 1990). Way (1977) found that gill nets lost in Newfoundland, Canada, waters continued to catch fish over several years, albeit at a decreased rate compared with tended nets. He also noted the attraction of crabs to fish caught in the nets; a finding which was frequently reported in later studies taking place in temperate waters. High (1985) monitored pieces of lost salmon gill net and found that, although nets were heavily overgrown with algae within a year, sea birds and fish were caught over a 3 yr period, while crabs continued to be tangled in the nets for a further 3 yr. Carr \& Cooper (1987) estimated that the catch rates of lost gill nets in a specific Canadian fishery were 15\% of those of active gill nets. According to Breen (1990) lost herring gill nets in British Columbia, Canada, continued to catch fish for $7 \mathrm{yr}$, while live fish were found in $8 \mathrm{yr}$ old gill nets retrieved in Norwegian waters (D. M. Furevik pers. comm. 1996). Recent studies by the Irish Sea Fisheries Board [Bord Iascaigh Mhara (BIM) 1995], involving the deployment of gill nets inshore $(15$ to $18 \mathrm{~m}$ ) and offshore $(80 \mathrm{~m})$, showed that nets set in deeper waters suffered much less fouling and consequently were more effective in fishing terms, with a greater long-term impact on fish and mammals

The scale of the ghost fishing problem is difficult to assess given the uncertainties regarding the amount of gear which is lost (Chopin et al. 1995). A number of studies have attempted to estimate the amount of lost nets in a given area using ROVs (Remotely Operated Vehicles) or by retrieving nets from the bottom with grappling equipment (Barney 1984, Carr \& Cooper 1987, Cooper et al. 1987, Carr 1988). Fosnaes (1975, in Breen 1990) estimated that 5000 Newfoundland cod Gadus morhua gill nets were lost annually. Way (1977) reported retrieving 148 and 167 nets in 48.3 and $53.5 \mathrm{~h}$ of trawling with a grappling device over a 2 yr period. Carr \& Cooper (1987) estimated that there were 2240 lost nets in a 64 mile $^{2}$ area of traditional gill netting grounds. According to a more recent review of the Canadian Atlantic fisheries 8000 gill nets $(2 \%$ of all active gill nets) were lost per year on average up to 1992 , resulting in an estimated loss of between 3000 and 30000 t of ground-fish in 1992 (Anon. 1995, Chopin et al. 1995). Globally, for all gill net fisheries, an estimate of a $1 \%$ loss rate per year has been suggested ( $\mathrm{Na}$ tional Resources Consultants, Inc. 1990, in Laist 1995).

The present study demonstrates that, under specific conditions, lost nets may continue to catch both target and non-target species for extended periods. However, given the wide range of conditions in which fishing gear can be lost, and the likelihood that nets lost in deep water may have a longer effective fishing life-span, it will be necessary to extend this study to take into consideration important factors such as depth and bottom type. In conjunction with such studies on the fate and impact of lost nets, the gear loss in commercial fisheries should be quantified. Useful appraaches may include surveying fishing vessel captains and owners for records of incidents of lost nets in conjunction with towing for lost nets with grappling devices. Only then will it be possible to fully assess the range and importance of unaccounted or incidental mortality associated with ghost fishing nets.

Acknowledgements. This work was funded in part by the EC (DG XIV ref. 94/095). We thank all the participants of the FANTARED project, and in particular Jorge Gonçalves, Luis Bentes, Pedro Lino, and the staff of IPIMAR who contributed in many ways. We also thank Michel Kaiser and 2 other anonymous referees whose suggestions greatly improved the manuscript. 


\section{LITERATURE CITED}

Anon. (1995) Prevention of ghost fishing in Atlantic Canada. Phase I. Report, Fisheries Management, Department of Fisheries and Oceans, Newfoundland, Canada

Barney W (1984) Lost gillnet retrieval project 1983-1984 Fisheries and Oceans, Fisheries Development Branch, Newfoundland Region, FDB-1983-84-26, Newfoundland, Canada

Blois S de (1992) The implementation of the galvanic time release mechanism on queen crab pots in the Gulf of St. Lawrence. A case of responsible fishing. Proc Mar Technol Soc Conf, Washington, DC, p 415

Bord lascaigh Mhara (BIM) (1995) Selectivity of fishing gears in Irish waters. Final Report, EU Contract BIO/ECO 1993/11

Breen PA (1987) Mortality of Dungeness crabs caused by lost traps in the Fraser river estuary, British Columbia. N Am J Fish Manage 7:429-435

Breen PA (1990) A review of ghost fishing by traps and gillnets. In: Shomura RS, Godfrey ML (eds) Proceedings of the Second International Conference on Marine Debris, 2-7 April 1989, Honolulu, Hawaii. US Dept Commerce, NOAA Tech Memo NMFS, NOAA-TM-NMFS-SWFSC154, p 571-599

Canário AVM, Erzini K, Castro M, Gonçalves JMS, Galhardo C, Ribeiro J, Bentes L, Cruz J, Souto P (1994) Estudos base para a consevaçāo dos ictiopovoamentos e gestāo da pesca costeira no litoral sudoeste. UCTRA, Universidade do Algarve e SNPRCN-APPSACV, Relatório final

Carr HA (1987) Impact on non-degradable marine debris on the ecology and survival outlook of sea turtles. Mar Pollut Bull 18(6B):352-356

Carr HA (1988) Long term assessment of derelict gillnet found in the Gulf of Maine. In: Oceans '88, Proceedings of the Marine Technology Society, p 984-986

Carr HA, Blott AJ, Caruso PG (1992) A study of ghost gillnets in the inshore waters of southern New England. In: MTS '92: Global Ocean Partnership. Marine Technology Society, Washington, DC, p 361-367

Carr HA, Cooper RA (1987) Manned submersible and ROV assessment of ghost gillnets in the Gulf of Maine. In: Proceedings Oceans ' 87 , The ocean-an international workplace, Halifax, NS, 2:622-624

Chopin F, Inoue Y, Matsushita Y, Arimoto T (1995) Sources of accounted and unaccounted fishing mortality. In: Baxter B, Keller S (eds) Solving bycatch: considerations for today and tomorrow. Proceedings of the Solving Bycatch Workshop, University of Alaska Sea Grant College Program Report No. 96-03, p 41-47

Colema FC, Wehle DHS (1983) Caught by accident. The fishermen's unwanted harvest. Oceans 4:65-69

Cooper RA, Carr HA, Hulbert AH (1987) Manned submersible and ROV assessment of ghost gillnets on Jeffreys and Stellwagen banks, Gulf of Maine. NOAA Undersea Research Program Research Report 88-4

Degange AR, Newby TC (1980) Mortality of seabirds and fish in a lost salmon driftnet. Mar Pollut Bull 11:322-323

Editorial responsibility: Otto Kinne (Editor),

Oldendorf/Luhe, Germany
Erzini K, Gonçalves JMS, Bentes L, Lino PG, Cruz J (1996a) Species and size selectivity in a Portuguese multispecies artisanal long-line fishery. ICES J Mar Sci 53:811-819

Erzini K, Santos MN, Monteiro CC, Gonçalves J, Bentes L, Lino P (1996b) A comparison of monofilament gillnet and small hook longline selectivity in a multispecies artisanal fishery in the Algarve, southern Portugal. Naga, The ICLARM Quarterly 9:29-32

Gerrodette T, Choy BK, Hiruki LM (1987) An experimental study of derelict gill nets in the central Pacific Ocean. SW Fisheries Center, NMFS, Honolulu Laboratory, Admin Rep $\mathrm{H}-87-18$

Gonçalves JMS, Bentes L, Lino PG, Ribeiro J, Canário A, Erzini K (1997) Weight-length relationships for selected fish species of the small-scale demersal fisheries of the south and south-west coast of Portugal. Fish Res 30 $253-256$

Henderson JR (1984) Encounters of Hawaiian monk seals with fishing gear at Lisianski Island. Mar Fish Rev 46: $59-61$

High WL (1985) Some consequences of lost fishing gear. In: Shomura RS, Yoshida HO (eds) Proceedings of workshop on the fate and impact of marine debris, 26-29 November 1984, Honolulu, Hawaii. US Dept Commerce, NOAA Tech Memo NMFS, NOAA-TM-NMFS-SWFC-54, p $430-437$

Kaiser MJ, Bullimore B, Newman P, Lock K, Gilbert S (1996) Catches in 'ghost fishing' set nets. Mar Ecol Prog Ser 145: $11-16$

Laist DW (1995) Marine debris entanglement and ghost fishing: a cryptic and significant type of bycatch? In: Baxter B, Keller $S$ (eds) Solving bycatch: considerations for today and tomorrow. Proceedings of the Solving Bycatch Workshop, University of Alaska Sea Grant College Program Report No. 96-03, p 33-39

Mathews CP, Gouda VR, Riad WT, Dashti J (1987) Pilot study for the design of a long life fish trap (gargoor) for Kuwait's fisheries. Kuwait Bull Mar Sci 9:221-234

Millner RS (1985) The use of anchored gill and tangle nets in the sea fisheries of England and Wales. Laboratory Leaflet 57. Ministry of Agriculture, Fisheries and Food, Directorate of Fisheries Research, Lowestoft

Mio S, Domon T, Yoshida K, Matsumura S (1990) Preliminary study on change in shape of drifting nets placed in the sea. In: Shomura RS, Godfrey ML (eds) Proceedings of the Second International Conference on Marine Debris, 2-7 April 1989, Honolulu, Hawaii. US Dept Commerce, NOAA Tech Memo NMFS, NOAA-TM-NMFS-SWFSC-154

Perrin WF, Donovan GP, Barlow J (eds) (1994) Gillnets and cetaceans. Report of the International Whaling Commission, Special Issue 15, IWC, Cambridge

Santos M. Monteiro C, Lasserre G (1996) Faune ichthyologique comparée de deux récifs artificiels du littoral de la Ria Formosa (lagune Portugal): résultats préliminaires. Oceanol Acta 19:89-97

Way EW (1977) Lost gill net (ghost net) retrieval project, 1976. Environment Canada, Fisheries and Marine Service, Industrial Development Branch, St Johns, Newfoundland

Submitted: July 22, 1997; Accepted: September 9, 1997 Proofs received from author(s): October 20,1997 